\title{
Are Smartphone Addiction. Fear of Missing Out (FoMO), and Conformity have impact for Phubbing from Millenial Generation?
}

\author{
Putri Metsa Pemayun, Fadhilah Suralaga \\ Faculty of Psychology, Syarif Hidayatullah State Islamic \\ University, Jakarta, Indonesia \\ putrimetsa.pemayun15@mhs.uinjkt.ac.id; \\ fadhilah.suralaga@uinjkt.ac.id
}

\begin{abstract}
This study aims to determine whether there is an influence of smartphone addiction, fear of missing out (FoMO), conformity, and demographic factors towards phubbing. The population of this research is generation $\mathrm{Y}$ who have communication devices and domiciles in JABODETABEK. The sample in this research is 301 people. Sampling using non-probability sampling techniques. Measuring tool used in this research is the scale of the phubbing scale instrument (PS), smartphone addiction scale-short version (SAS-SV), fear of missing out scale (FoMOS), and scale of conformity. Test the validity of measuring instrument used is the technique of confirmatory factor analysis (CFA). Hypothesis testing in this research using multiple regression analysis through IBM SPSS statistics 20. The results of this research indicate that there is a significant influence on smartphone addiction variables, fear of missing out (FoMO), conformity, and demographic factors to phubbing of 0,391 or $39,1 \%$ of the remaining $60,9 \%$ is influenced by other variables. Based on the results of the hypothesis testing of each variable that has been done, there are one variable significant influence on phubbing of smartphone addiction.
\end{abstract}

Keywords: Phubbing, Smartphone Addiction, Fear of Missing Out (FoMO), Conformity

\section{Introduction}

The development of an increasingly modern era makes technology continue to evolve to meet human needs. tribal era people communicate verbally and face to face so that in this digital era, people no longer have to meet the other person to deliver messages because communication tools such as smartphones are devices that are able to deliver the message in seconds [5]. APJII's research results (2018) show that smartphones are the most widely used devices reaching $70.96 \%$. Not infrequently, someone does not only use a smartphone that is owned to fill in the blanks, but continues when doing two conversations simultaneously, namely communication directly and in cyberspace, when eating dinner together or other activities placing a smartphone near him just in case, and can't go through meetings without checking the smartphone first. This phenomenon is known as phubbing [10].

Phubbing is the behavior of someone who sees his telephone during a conversation with another person, deals with his telephone, and avoids interpersonal communication [6]. These dimensions include (i) smartphone addiction (ii) fear of missing out (FoMO), (iii) 
conformity. When this behavior is carried out continuously it can show the level of relationship satisfaction and the beliefs of the other person to be less meaningful and empathy will decrease when one individual uses a smartphone [11]. [13] show $95 \%$ of 349 students in Turkey admit they use smartphones and do phubbing in class at least once or twice, and 32\% do it every day. In America, $68 \%$ of respondents feel the need to tell someone who is having dinner with a partner in a company not to see the message until they finish eating [2].

\section{Literature Review}

\subsection{Smartphone Addiction}

Addiction to smartphones that are likely to be a social problem indicates some characteristics of addiction, such as intolerance, withdrawal, difficulty doing daily activities, and impulse control disorders [8]. According to [9] smartphones can cause problems when overused, for example causing maladaptive behavior seen in pathological impulse control disorders that can interfere with school or work, reduce social interaction in real life, reduce academic ability, cause problems in relationships, and affect health physically including blurred vision and pain in the wrist or back of the neck. Smartphone addiction explains smartphone use that is excessive and difficult to control and brings widespread influence in someone else's life in a negative way [5].

\subsection{Fear of Missing Out (FoMO)}

A situation where someone has the desire to play or is only limited to seeing social media in order to stay connected continuously with what other people do in cyberspace [11]. In this case, the fear of losing someone about what others are doing can be seen from two things, including not meeting the psychological needs of relatedness and not meeting the psychological needs of self. According to JWT Marketing Communication in [1]. FoMO is a feeling of discomfort and sometimes everything that is being experienced by someone that he feels loses information on what his colleagues are doing, loses information he wants to know, or someone else has more information that is better than what he have it.

\subsection{Conformity}

A form of behavior change or trust to be in harmony with others [10]. Conformity does not only act in accordance with the actions taken by others, but also influenced by how they act. Conformity is divided into 2 kinds including compliance (acceptance) and acceptance (acceptance). Conformity can also be interpreted as a tendency to change a person's beliefs or behavior to suit the behavior of others [4]. Most teens are considered free to choose their own clothes and hair, but most people prefer to wear clothes like other people in their social groups and follow the latest fashion trends.

\section{Research Hypothesis}

This study wants to find out more about the determinants of phubbing. In this context, the research hypothesis was tested, namely there was a significant effect of smartphone addiction, fear of missing out (FoMO), and conformity to phubbing. 


\section{Method}

\subsection{Research Design}

In this study, we aim to determine whether there is an influence of the dimensions of smartphone addiction, fear of missing out (FoMO), conformity to phubbing.

\subsection{Participant}

Research has been carried out on 301 respondents who are included in the $Y$ generation or millennial generation population with criteria born in 1980-2000, have smartphones or other communication devices, domiciled in JABODETABEK. Retrieval of respondents in this study using non- probability sampling techniques by collecting data using an online questionnaire (google form) that is disseminated through social media instagram, twitter, and facebook.

\subsection{Measurement}

Data is collected through the use of four scales. The Likert type scale was developed in this study and controlled for measuring validity and reliability which includes (i) The Phubbing Scale [7]; (ii) Smartphone Addiction Scale-Short Version [8]; (iii) Fear of Missing Out Scale [11]; (iv) Scale of conformity [10].

\section{Results}

This study obtained data from 301 respondents who had filled out questionnaires through google form. Based on 301 questionnaires that have been filled, all respondents answered the statement given well. Description of respondents in this study based on demographic data can be seen that the number of male respondents 112 people $(37.2 \%)$ and female respondents 189 people $(62.8 \%)$.

In this study, we tested the hypothesis with multiple regression analysis using IBM SPSS 20 software to see the magnitude of R square to find out what percentage (\%) of the DV variant described by IV, second whether overall IV had a significant effect against DV, then finally see the significance of the regression coefficients of each IV.

Table 1:R.Square

\begin{tabular}{lcccc} 
Table 1:R.Square \\
\hline \multicolumn{7}{c}{ Model Summary } \\
\hline Model & R & R Square & $\begin{array}{c}\text { Adjusted R } \\
\text { Square }\end{array}$ & $\begin{array}{c}\text { Std. Error of } \\
\text { the Estimate }\end{array}$ \\
\hline 1 &, $639^{4}$ &, 408 &, 394 & 6,94101 \\
\hline
\end{tabular}

In this study, we tested the hypothesis with multiple regression analysis using IBM SPSS 20 software to see the magnitude of R square to find out what percentage (\%) of the DV variant described by IV, second whether overall IV had a significant effect against DV, then finally see the significance of the regression coefficients of each IV. 
Table 2: ANOVA

\begin{tabular}{|c|c|c|c|c|c|c|}
\hline \multicolumn{7}{|c|}{ ANOVA } \\
\hline Model & & Sum of & df & Mean Square & $\mathrm{F}$ & Sig. \\
\hline 1 & $\begin{array}{c}\text { Regression } \\
\text { Residual } \\
\text { Total }\end{array}$ & $\begin{array}{l}9724,517 \\
14116,035 \\
23840,552\end{array}$ & $\begin{array}{c}7 \\
293 \\
300\end{array}$ & $\begin{array}{c}1389,217 \\
48,178\end{array}$ & 28,835 &, $000^{5}$ \\
\hline
\end{tabular}

In the ANOVA table above it can be seen that the sig value. in the far right column is 0,000 . Thus it is known that the value of sig. $<0.05$. So the null hypothesis (nil) which states there is no significant influence from smartphone addiction, FoMO, conformity to phubbing is rejected. That is, there is a significant influence from smartphone addiction, FoMO, conformity to phubbing.

Table 3: Regression Coefficient

\begin{tabular}{|c|c|c|c|c|c|c|}
\hline \multirow{2}{*}{\multicolumn{2}{|c|}{ Model }} & \multicolumn{3}{|c|}{ Coefficients } & \multirow[b]{3}{*}{ t } & \multirow[b]{3}{*}{ Sig. } \\
\hline & & $\begin{array}{l}\text { Unst. } \\
\text { Co }\end{array}$ & $\begin{array}{l}\text { ardized } \\
\text { cients }\end{array}$ & $\begin{array}{l}\text { Standardized } \\
\text { Coefficients }\end{array}$ & & \\
\hline & & $\mathrm{B}^{\mathrm{Co}}$ & $\begin{array}{l}\text { cients } \\
\text { Std. Error }\end{array}$ & $\begin{array}{l}\text { Coefficients } \\
\text { Beta }\end{array}$ & & \\
\hline \multirow{8}{*}{1} & (Constant) & 7,970 & 4,169 & & 1,911 & \\
\hline & Gangguan Hari & 107 & 054 & , 100 & 1,987 & 048 \\
\hline & Penaribar_Ditri & 233 & 056 & 245 & 4,152 &, 000 \\
\hline & Intolercussi & ,443 & 0,066 & 398 & 6,684 &, 000 \\
\hline & Tidak Relatedbess. & 028 &, 048 & 028 &, 573 &, 567 \\
\hline & Tidak Self & ,003 & 054 &, 003 &, 051 & 960 \\
\hline & Pememiham &, 018 & ,049 & ,018 &, 374 &, 708 \\
\hline & Peneringan & ,008 &, 050 & ,008 &, 161 & 872 \\
\hline
\end{tabular}

In the table of regression coefficients above it can be seen that smartphone addiction (disruption of daily life, withdrawal, intolerance) has a significance of $<0.05$. Thus this variable has a significant effect on phubbing. Whereas, FoMO (not fulfilling psychological needs for relatedness, not fulfilling psychological needs for self) and conformity (compliance), acceptance) has a significance of $>0.05$. Thus, this variable has a significant but not significant effect onphubbing.

Table 4: Homogenety

\begin{tabular}{cccccc}
\hline No. & Jenis Kelamin & N & Mean & Std.Deriation & Sig. (2-tailed) \\
\hline 1. & Pria & 112 & 48,4324 & 9,42023 & 0,019 \\
2. & Wanita & 189 & 50,9291 & 8,49028 & 0,019 \\
\hline
\end{tabular}

In the homogeneity test table above, it can be explained that the homogeneity of data testing is done by the test of homogenety of variances for male and female gender. From the results of the homogeneity test it is known that the male mean value is lower at 48.4324 while the mean value of women is 50.9291 with significance $(2$-tailed) $<0.05$, which is equal to 0.019 . Then it can be concluded that female sex tends to be higher in phubbing compared to male sex.

Table 5:Variances proportion IV into DV

\begin{tabular}{|c|c|c|c|c|c|c|c|c|c|}
\hline \multicolumn{10}{|c|}{ Model Summary } \\
\hline \multirow[b]{2}{*}{ Model } & \multirow[b]{2}{*}{$\mathbf{R}$} & \multirow[b]{2}{*}{$\begin{array}{c}\mathbf{R} \\
\text { Square }\end{array}$} & \multirow[b]{2}{*}{$\begin{array}{l}\text { Adjusted } \\
\text { R Square }\end{array}$} & \multirow{2}{*}{$\begin{array}{c}\text { Std. } \\
\text { Error of } \\
\text { the } \\
\text { Estimate }\end{array}$} & \multicolumn{5}{|c|}{ Change Statistics } \\
\hline & & & & & $\begin{array}{c}\mathbf{R} \\
\text { Square } \\
\text { Change }\end{array}$ & $\begin{array}{c}F \\
\text { Change }\end{array}$ & dfl & $\mathrm{df} 2$ & $\begin{array}{c}\text { Sig. F } \\
\text { Change }\end{array}$ \\
\hline 1 &, $342^{a}$ &, 117 &, 114 & 8,39032 &, 117 & 39,657 & 1 & 299 &, 000 \\
\hline 2 &, $561^{\mathrm{b}}$ & , 315 & , 310 & 7,40538 & , 197 & 85,826 & 1 & 298 &, 0 \\
\hline 3 & $638^{c}$ &, 406 &, 400 & 6,90235 &, 092 & 46,018 & 1 & 297 &, 000 \\
\hline & $638^{\mathrm{d}}$ & 407 & 399 & 6,90844 &, 001 & 477 & 1 & 296 & 490 \\
\hline 5 & $638^{\mathrm{e}}$ & 407 &, 397 & 6,91996 & 000 & 015 & i & 295 & 903 \\
\hline 6 & $63 g^{f}$ & 408 & 396 & 6,92950 &, 000 & 188 & 1 & 294 &, 665 \\
\hline 7 & 6393 & 408 &, 394 & 6,94101 & 000 & 026 & 1 & 293 & 872 \\
\hline
\end{tabular}


In the table of variance proportions for each variable on phubbing above, it is known that daily life disorders from smartphone addiction contribute 0.100 or $11.7 \%$ to the phubbing variant, withdrawal from smartphone addiction contributes 0.197 or $19.7 \%$ to the phubbing variant, intolerance from smartphone addiction contributed 0.092 or $9.2 \%$ to the phubbing variant. Furthermore, the non-fulfillment of the psychological needs of relatedness from FoMO contributes 0.001 or $1 \%$ to the phubbing variant, the failure to fulfill the psychological need for self from FoMO contributes 0,000 or $0.0 \%$ to the phubbing variant. Then, the fulfillment (compliance) of conformity contributes 0,000 or $0.0 \%$ to the variants of phubbing and acceptance of conformity contributing 0,000 or $0.0 \%$ to the phubbing variant.

\section{Discussion}

In this study, we found that smartphone addiction (daily life disruption, withdrawal, intolerance), FoMO (not fulfilling psychological needs for relatedness, not fulfilling psychological needs for self), and conformity (compliance) and acceptance)) has a significant influence on phubbing with the value of the contribution of all dimensions to phubbing by 0.408 or $40.8 \%$ and the remaining $59.2 \%$ is influenced by other variables outside of this study.

Based on the results of the study, the variable that has the greatest influence on phubbing is smartphone addiction which consists of disruption of daily life, withdrawal, and intolerance. This is in accordance with the research conducted by [7] that smartphones facilitate human life that causes problems in human life, which causes excessive use of technology, high levels of involvement and eventually addiction to smartphones. Someone who has an addiction to a smartphone tends to do phubbing which allows showing disrespect for someone who is communicating with them, ignores it, and prefers a virtual environment rather than real life.

The other variable is FoMO which consists of not fulfilling the psychological needs of relatedness and not fulfilling the psychological needs of self has an influence but not significant to phubbing. That is, in this study FoMO did not affect phubbing on generation Y. In this case, it could be that someone who is experiencing unmet psychological needs for high relatedness raises a fear of losing height has a tendency not to do phubbing because it tries to fulfill the closeness or desire to connect with other people around him. Whereas, a person who has not fulfilled psychological needs for low relatedness creates a fear of losing low has a tendency to do phubbing because of the lack of closeness or the desire to connect with other people around him.

In addition, someone who experiences fear of losing high psychological needs for high self raises has a tendency to become phubbing because it tries to fulfill the inherent desires of the individual to feel effective in interacting with other people around him and individually beliefs to take actions or certain behaviors efficiently and effectively. Whereas, a person who experiences unmet psychological low self- causes of fear of low loss has a tendency to do phubbing because of the unfulfilled desires of inherent in the individual to feel effective in interacting with others who are around him or her beliefs and take certain actions or behaviors efficiently and effectively.

This is not in line with previous research from JWT Marketing Communication in [1] who say that someone does phubbing because they are afraid of losing information that tends 
to be more anxious, irritable, feel ignorant, and have low self-esteem because it is almost impossible not to know what other people are doing and say at any time.

The next variable is conformity which consists of fulfillment (compliance) and acceptance (acceptance) has a significant but not significant effect on phubbing. That is, in this study conformity does not affect phubbing on generation Y. In this case, someone who has high conformity can have a tendency to do phubbing or vice versa. Likewise, someone who has low conformity can have a tendency to do or not do phubbing, it could be more influenced by the level of addiction of their smartphone. This is not in line with the statement from [4] which states that conformity is a tendency to change a person's beliefs or behavior to suit the behavior of others. Conformity does not only act in accordance with the actions of others, but also influenced by how they act.

Based on the discussion described above, this study explains how the relationships between variables have an influence on phubbing. The results of this study indicate that variables affecting phubbing have an influence of only $40.8 \%$ of IV studied, so that there are still $59.2 \%$ of other variables affecting phubbing not included in this study. The results of this study can actually be elaborated for broader research by doing a number of things, including analyzing phubbing based on demographic data so as to get a picture of respondents with specific qualifications, using methods or other data collection with a clear population of data, and examining other dimensions which might affect phubbing.

\section{Conclusion}

In this study it can be seen that the null hypothesis which states that no influence from all dimensions of phubbing is rejected. The conclusion of this study is that there are significant effects of smartphone addiction (daily life disruption, withdrawal, intolerance), FoMO (not fulfilling psychological needs for relatedness, non-fulfillment of psychological needs for self), and conformity (compliance), acceptance) of phubbing. Based on the results of hypothesis testing, from the significance of each regression coefficient to phubbing, smartphone addiction variables have a significant regression coefficient, while FOMO and conformity have an effect but not significant.

\section{Directions For Future Research}

In this study we have theoretical advice and practical advice. For theoretical advice, among them can pay attention to demographic factors for further research such as age, occupation, status, can be used samples that have a clear population the amount of data using purposive sampling method or data collection in the form of a physical questionnaire, and can use other variables that are suspected can affect phubbing more strongly including addiction to the internet, addiction to social media, addiction to games, self control.

For practical suggestions, it is expected that respondents can reduce the use of communication devices, especially smartphones, while with other people by disabling smartphones while it can be a form of respecting others who are around us and when the other person is talking so that no one feels neglected. It is expected that respondents can use social media wisely and full of awareness that everyone has the appearance of life that they want to show differently and do not need to feel anxious and follow all the activities or conversations of others that have nothing to do with personal life, and expected to respondents doing fun 
activities with other people that are more beneficial and positive by expanding the existing socialization in real life, especially with the closest people so that the quality of the relationship is felt more closely.

\section{References}

[1] Abel, J.P., Buff, C. L., Burr, S. A. (2016). Social media and the fear of missing out: scale development and assessment. Journal of Business \& Economics Research, 14, 33-44.

[2] Alto, P. (2016) Phubbing explained: delvv survey reveals pressures behind antisocial smartphone behavior. Diunduh pada tanggal 12 Oktober 2018 pukul 21:10 WIB dari https://www.prnewswire.com/n ews-releases/phubbing- explained-delvv-survey-reveals- pressuresbehind-antisocial- smartphone-behavior- 300301942.html

[3] APJII. (2017). Penetrasi \& perilaku pengguna internet indonesia: Survey 2017. Jakarta: APJII

[4] Cialdini, Robert. B. \& Noah J. Goldstein. (2004). Social influence: Compliance and conformity. Arizona State University, Tempe, Arizona 85287-1104.

[5] Gokçearslan, S., Mumcu, F. K., Haslaman, T., Cevik, Y. D., (2016). Modelling smartphone addiction: the role of smartphone usage, self- regulation, general self-efficacy, and cyberloafing in university student. Computer and Human Behavior, 63, 639-649.doi: 10.1016/j.chb.2016.05.091

[6] Hanika, I., M. (2015). Fenomena phubbing di era milenia (ketergantungan seseorang pada smartphone terhadap lingkungannya). Jurnal interaksi, vol.4 no.1: 42-51

[7] Karadag, E., Tosuntas, S. B., Erzen, E., Duru, P., Bostan, N., Sahin, B. M., et al. (2015). Determinants of phubbing, which is the sum of many virtual addictions: a structural eqution model. Journal of Behavioral Addictions, 4(2), 60-74.doi: 10.1556/2006.4.2015.005

[8] Kwon, M., Yang, S., (2013). The smartphone addiction scale: development and validation of a short version for adolescent. PLOS One, 8 (12), 1-7.doi: 10.1371/journal.pone.008355

[9] Mok, J. Y., et al. (2014). Latent class analysis of internet and smartphone addiction in college students. Neuropsychiatric Disease and Treatment. 10, 817-828.

[10] Myers, D. G., (2012). Social psychology: tenth edition. New York: Mc Graw Hill Companies.

[11] Przybylski, A. K., Murayama, K., DeHaan, C. R., Gladwell, V. (2013). Motivational, emotional, and behavioral correlates of fear of missing out. Computer in Human Behavior, 29, 1841-1848. http://dx.doi.org/10.1016/j.chb.20 13.02.014

[12] Roberts, J. A., David, M. E. (2016) My life has become a major distraction from my cell phone: partner phubbing and relationship satisfaction among romantic partner. Computer in Human Behavior, 54, 134-141.http://dx.doi.org/10.1016/j.chb.20 15.07.058.

[13] Ugur, N. G., Koc, T. (2015). Time for digital detox: misuse of mobile technology and phubbing. Social and Behavioral Science, 195, 1022-1031 